Intersections

Canadian Journal of Music

Revue canadienne de musique
Intersections CANADAN IOURAA OO NUSTC

\title{
Theodore Gracyk and Andrew Kania, eds. 2011. The Routledge Companion to Philosophy and Music. New York: Routledge. ISBN 978-0-415-48603-3
}

\section{Murray Dineen}

Volume 31, numéro 1, 2010

URI : https://id.erudit.org/iderudit/1009290ar

DOI : https://doi.org/10.7202/1009290ar

Aller au sommaire du numéro

Éditeur(s)

Canadian University Music Society / Société de musique des universités canadiennes

ISSN

1911-0146 (imprimé)

1918-512X (numérique)

Découvrir la revue

Citer ce compte rendu

Dineen, M. (2010). Compte rendu de [Theodore Gracyk and Andrew Kania, eds. 2011. The Routledge Companion to Philosophy and Music. New York: Routledge. ISBN 978-0-415-48603-3]. Intersections, 31(1), 185-187.

https://doi.org/10.7202/1009290ar

All Rights Reserved (C Canadian University Music Society / Société de musique des universités canadiennes, 2012
Ce document est protégé par la loi sur le droit d'auteur. L'utilisation des services d’Érudit (y compris la reproduction) est assujettie à sa politique d'utilisation que vous pouvez consulter en ligne.

https://apropos.erudit.org/fr/usagers/politique-dutilisation/ 


\section{BOOK REVIEWS / RECENSIONS}

Theodore Gracyk and Andrew Kania, eds. 2011. The Routledge Companion to Philosophy and Music. New York: Routledge. ISBN 978-0-415-48603-3.

I have two initial impressions of this book. First, it reads like the proceedings of an enormous, imaginary conference, one that for the rest of my life I shall regret missing. Second, like many conferences, the selection of papers shows a certain random quality-unlikely bedfellows put together to form dubious topic sessions. In essence, the book is an embarrassment of riches: there is so much here, but the links between its fifty-two chapters, and indeed its mandate, are embarrassingly unclear. But who is to complain of abundance when so little is being done these days in music aesthetics.

The book is a Routledge "Companion," after all, and under that rubric all kinds of collections are concocted. Perhaps the problem of diversity arises, however, from the title "Philosophy and Music," not "Philosophy of Music," which would limit it considerably (putting the weight on philosophy), or "Music in Philosophy," which, again, would be confining (freighting music). The problem of the collection lies in delimiting the scope of "and." And in determining the exact nature of the conjunction. Are music and philosophy equal partners? It would seem so on occasion. But if music scholars don't speak the languages of philosophy, at least with some fluency, then by default won't music become the language of exchange (as is largely the case here)? The resulting balance between music and philosophy varies: on some occasions the relationship is drawn tightly, between equal partners, but on others it seems as if one is faced with two quite separate endeavours, these waving to each other across a gulf of indifference.

Of the fifty-odd writers (Roger Scruton appears twice), they separate themselves into groups that, if history rings true, should be antipathetic on occasion. Consider, for example, the Atlantic: on the one side, there is a small host of Brits, including Scruton, Anthony Gritten, Allen Moore, Malcolm Budd, Noël Carroll, and Eric Clarke. On the other side, the Americans (who loom large here): those from the circle of the Journal of Aesthetics and Art Criticism such as Jenefer Robinson, Philip Alperson, and Stephen Davies, a few Society for Music Theory theorists such as Justin London, Fred Maus, and Joseph Dubiel, seemingly token American Musicological Society types Thomas Mathieson and Thomas Grey, and the philosopher Ray Jackendoff (no sign of Fred Lehrdahl). There are some jazz scholars, Bruce Benson and Lee Brown (and Gracyk himself), some ethnomusicologists, Stephen Blum and Peter Manuel, and several other notables who don't fall easily into camps, such as Kathleen Higgins, whose work in music and moral education was groundbreaking, but 
in this instance concerns herself with synesthesia. And there are five declared Canadians, all philosophers (none to my knowledge participate regularly in CUMS): James Young, Jeanette Bicknell, Diana Raffman, David Davies, and Carl Manuel. (Note to president: we must invite these people to a meeting.) For years now, the two sides of the Atlantic did not see eye to eye on approaches to philosophy or music (as was certainly the case with music theory in days past). Former hurts have been remedied, however, but this collection would give no indication of that fact. There is little antipathy, but not much sympathy-just the yawning gulf, for the reasons outlined above, and principally a lack of a clearly articulated shared mandate-a reason to talk to one another. Perhaps the collection would have worked better with the title Philosophies and Music. (I won't even mention the fact that Continental philosophy is neglected here almost completely.)

These disparate perspectives are brought together in six parts, each of which shows the problem of lack of focus, some more so than others: "General Issues," "Emotion," "History," "Figures" (which starts with Plato and ends with Adorno, whew!), "Kinds of Music," and then a catch-all "Music, Philosophy, and Related Disciplines." "History," for example, contains "Classical Aesthetic Traditions of India, China, and the Middle East" (Manuel and Blum), which does have historical content. But it has "Analytic Philosophy and Music" (Davies), primarily a survey of aesthetics since 1900, and then "Continental Philosophy and Music" (Tiger Rolholt), which has a touch of Nietzsche, then a two-page review of Lydia Goehr's Imaginary Museum (why isn't Goehr in this collection?), a turn to Bourdieu under the subheading "Sociopolitical," and under "Anti-scientism" a discussion of the long-neglected Thomas Clifton. Not to complain, for each of these six parts and their component chapters is worthy in its own right, but the links that could have made the collection interesting in its own right are largely neglected, quite unfortunately.

I think the problem is most acute with an article such as "Music Theory and Philosophy," by Judy Lochhead, a formidable music philosopher in her own right. A pencil-sketch historical survey primarily of music theory and theorists, it has only a few philosophical asides. The bulk will be familiar to music theorists but would serve as a useful shopping list for philosophers unfamiliar with the field. Unfortunately there are only a few general observations about the relationship between theory and philosophy, this from a scholar quite capable of observing their bonds. A truly critical approach would have been welcome, for the links that bridge modern music theory to philosophy are not without their weaknesses, quite aside from the strengths that Lochhead assumes. Could this be done under the rubric of a "Companion"? Yes. There is nothing that forbids advanced thoughts as companions to the layperson. For if this is not the case, then "companions" such as these simply devolve to "readers"-lite.

There are chapters, however, in which the authors rise to their best. I shall list only a few that strike me as well worthy of note. Malcolm Budd treads gently but decisively over the perennial thorn of "musical emotion," drawing attention in particular to recent work by Jenefer Robinson (oft cited throughout the collection) among others. Put together with "Arousal Theories," by Derek 
Matravers, "Expression Theories," by Robinson herself, and "Resemblance Theories," by Saam Trivedi, the Budd works as a kind of tidying mechanismsuccinctly pulling together an issue given to messy sprawl in other forums (I wish that "Style" by Jennifer Judkins had risen to the same level). Kathleen Marie Higgins's "Visual Music and Synesthesia" is not so much a "companion" as a Wegweiser, a signpost signalling where research in this remarkable phenomenon, the confusion of sight and sound, might go. In fact, it is these basic areas of musical understanding that constitute the strength of the book. Other, more complex subjects, such as phenomenology or Adorno, simply cannot be done justice in the scope allotted the authors. Indeed, these are the strengths of the Journal of Aesthetics and Art Criticism, which as noted above is the parent journal, if only implicitly, for the Companion.

Quite apart from useful insights into potential avenues of research to be gleaned from the contributors here, the collection might have served as a text for a seminar, be it graduate or advanced undergraduate. Lacking any substantial texts on aesthetics and music, we certainly need something of that sort. But with a price tending toward $\$ 200$, it levitates itself quite out of the market, certainly the undergraduate market. (It is available as an e-book, possibly in your university's collection.) More's the shame. Perhaps one of our textbook publishers would take up the slack with a much smaller, less expensive collection suited to classroom use.

Murray Dineen

Alan Gillmor, ed. Eagle Minds: Selected Correspondence of Istvan Anhalt and George Rochberg, 1961-2005. Waterloo: Wilfrid Laurier University Press, 2007. xliii, 426 pp. ISBN 978-1-55458-018-7.

[Editor's Note: As this issue was going to press, István Anhalt passed away in Kingston, Ontario on February 242012 at the age of 92. A celebration of his life and music is being planned for a future date.]

Eagle Minds illuminates the deep intellectual and spiritual bond that composers Istvan Anhalt and George Rochberg cultivated during the course of their long friendship, documenting almost a half-century's worth of written correspondence between them. Selected and edited by the Canadian musicologist Alan Gillmor, the prolific exchange-over 250 letters written from between 1961 and Rochberg's death in 2005-comprises a detailed account of Anhalt's and Rochberg's individual pursuits as composers navigating the political and cultural tumult of the twentieth century. The collection offers a fascinating insight into both composers' personal lives as well as the lives of their worksoften from the seeds of inspiration through to their concert premieres and critical reception-unfolded in a conversation spanning Rochberg's and Anhalt's massive career arcs. Scholars with particular interest in either composer 